\title{
THE FEMALE PARTICIPATION IN THE ACADEMIC PRODUCTION ON CAPITAL STRUCTURE IN BRAZILIAN JOURNALS
}

\author{
M. E. A. de Oliveira', F. I. A. B. ALVES', J. L. SOUZA \\ Universidade Federal do Ceará1,2,3 \\ ivandborges@alu.ufc.br ${ }^{2}$
}

Artigo submetido em 30/01/2019 e aceito em 06/05/2019

DOI: $10.15628 /$ holos.2019.8255

\section{ABSTRACT}

Capital structure is one of the central themes of Corporate Finance. The development of theories and the range of empirical research on the behaviors and determinants of the capital structure are striking. Despite this interest in the subject, few studies have focused on the characteristics of this academic production, especially work on female participation. Thus, this study aims to analyze the female participation in academic production on capital structure in Brazilian periodicals. The collection of the articles of the sample was done through Portal Periódicos/Capes, SciELO and SPELL databases. The nonprobabilistic sample, obtained from the search in the databases, comprised 195 articles, written by 412
\end{abstract}

authors from 97 different institutions, published by 66 journals. Through the bibliometric analysis, it was observed that the female participation is smaller than the male participation. The main findings identified that only $29 \%$ of the authorship of the articles belonged to women; that historically female participation is lower than male participation; that authors prefer to produce their articles in partnership and the more authors there are in an article, the greater the presence of women in that article; the highest titers had a smaller contingent of women; of the most productive authors, only three are women; female participation was higher than male participation in only two of the 11 most representative institutions.

KEYWORDS: Female participation, Capital structure, Journals, Brazil.

\section{A PARTICIPAÇÃO FEMININA NA PRODUÇÃO ACADÊMICA SOBRE ESTRUTURA DE CAPITAL EM PERIÓDICOS BRASILEIROS}

\section{RESUMO}

Estrutura de capital é um dos temas centrais das Finanças Corporativas. É marcante o desenvolvimento de teorias e - leque de pesquisas empíricas sobre os comportamentos e determinantes da estrutura de capital. Apesar desse interesse pelo tema, poucos trabalhos se debruçaram sobre as características dessa produção acadêmica, em especial trabalhos sobre a participação feminina. Dessa forma, esse estudo tem como objetivo geral analisar a participação feminina na produção acadêmica sobre estrutura de capital nos periódicos brasileiros. A coleta dos artigos da amostra se deu através das bases Portal Periódicos/Capes, SciELO e SPELL. A amostra não probabilística, obtida da busca nas bases de dados, compreendeu 195 artigos, escritos por 412 autores provenientes de 97 diferentes instituições, publicados por 66 periódicos. Através da análise bibliométrica, observou-se que a participação feminina é menor que a masculina. Os principais achados identificaram que apenas $29 \%$ das autorias dos artigos são de mulheres; que historicamente a participação feminina é menor que a masculina; que os autores preferem produzir seus artigos em parceira e quanto mais autores há em um artigo, maior a presença de mulheres nesse artigo; as titulações mais elevadas tiveram um menor contingente de mulheres; dos autores mais produtivos, apenas três são mulheres; a participação feminina foi maior que a masculina em apenas duas das 11 instituições de maior representatividade.

PALAVRAS-CHAVE: Participação feminina, Estrutura de capital, Periódicos, Brasil. 


\section{INTRODUCTION}

Capital structure is an important theme within the field of Corporate Finance, since decisions related to the adjustment of the funding sources of the entity's projects can impact the investment decisions, the value of the company and the financial commitment of the entity. Associated to this, the greater interest of the researchers on the subject, evaluated by the volume of empirical researches, emphasizes that it is an area of relevant interest in the scientific field.

Theories have been proposed to explain how firms choose how their capital structure will be composed (which and in what volume and at what time the sources of finance will be), are theories based on the irrelevance of the capital structure, a balance between benefit and cost of debt (Tradeoff), hierarchy of sources of financing (Pecking order), opportunistic behavior of actions (Market timing), among others (Baker \& Wurgler, 2002, 2007; Correa, Basso, \& Nakamura, 2013; Lima, Lima, Lima, \& Pereira, 2012; Modigliani \& Miller, 1958, 1963; Myers, 1984; Padilha \& Silva, 2016; ShyamSunder \& Myers, 1999).

In addition to the development of these theories, there is a volume of empirical research that aims to analyze the dynamics of the theme. Despite this volume of research, we did not identify a study that analyzed the female participation in the production of these surveys. Because this is an important topic within Corporate Finance, due to the volume of research carried out in this area and because few bibliometric articles on this production have been developed (especially papers on female participation), this article aims to contribute to a better understanding of the characteristics of scientific production on capital structure.

The problem of female participation in science historically has to face social barriers, marked by machismo. Although women have prominent roles in science, notably with big names that have contributed significantly in their research areas, the issue of female participation is still timid in scientific production. Some areas, such as Finance, are marked by greater female representativeness, especially when considering the most qualified researchers.

The literature identifies that two mechanisms are associated with this barrier to greater female participation in scientific production: vertical segregation and horizontal segregation. Vertical segregation refers to the barrier in which women can not hold positions of leadership, should remain in subordinate positions or can not progress in the professional choices, thus being at the lower hierarchical levels. In turn, horizontal segregation addresses the social barrier in which access to certain functions is prohibited for women. So some functions are reserved for men (scientist, politician, businessman, manager, intellectual, among others) and women (secretary, teacher of children's education, domestic, manicure, etc.). That is, even if a woman overcomes the barrier of horizontal segregation and pursues the profession of scientist, she may find it difficult to progress in her career and gain notoriety among her peers, bumping into the barrier of vertical segregation.

This paper intends to answer the following research question: What are the characteristics of the national scientific production on capital structure as to the genre of the authors? For this, 
the following general objective was defined: to analyze the female participation in the academic production on capital structure in the Brazilian journals.

A bibliometric study was developed with 195 articles on the subject resulting from the search in the databases Portal PeriódicosCapes, SciELO and SPELL. We analyzed the female participation in the sample, the historical (in) evolution of this participation, the most prolific authors, the most representative institutions and the aspect of the authors' regionality.

This article is organized in five sections. The first of these corresponds to this introduction. The second section presents the theoretical reference of the research, which discusses capital structure and the interest of researchers and the most recurrent theories of the subject; then a discussion of female participation in science and the barriers to women's insertion and advancement in the academic arena begins, closing the section with a listing of previous studies that have analyzed women's participation in their areas of study. The third section is dedicated to the presentation of the methodological aspects of the research. In section four, the main results of the research are presented and discussed. In the last section the main conclusions of the research.

\section{THEORETICAL FOUNDATION}

\subsection{Capital structure}

The capital structure is one of the central themes in Corporate Finance, along with investment and dividend policy. The financial decisions taken when adjusting the capital structure adopted by the company affect the value of the company and the relationship with shareholders and creditors (Alves \& Crisóstomo, 2018). It is understood as the combination of equity and thirdparty resources in order to optimize the use of financing sources (Schroeder, Clark, \& Cathey, 2005). Thus, the capital structure can be considered as the composition and distribution of the financing sources of the entities (debt, equity, shares, debt financed with the government, among other sources), considering the amount of own resources and of third parties.

Organizations seek to obtain resources that promote the greatest benefit between cost and utility. In fact, the company always aims to have a portfolio of projects to be developed. On the other hand, the supply of available credit is not always sufficient to finance all the projects of the company. Thus, companies need to evaluate their projects as to the viability of resources to finance them (Crisóstomo, 2011).

The adjustment of the composition of the sources of financing is the object of analysis of the research on capital structure. Among these studies, there are those who have verified whether the capital structure of an organization influences its value or the researches that verify how this adjustment occurs - if there is any preference - and those that verify the factors that influence. From these researches, theories have been proposed that seek to explain decisions related to the theme: such as the irrelevance of Modigliani and Miller's capital structure, Trade-off theory, Pecking Order theory, Market Timing. 
The theory of the irrelevance of the capital structure over firm value is the result of one of the conclusions of the study by Modigliani and Miller (1958). The authors conclude that the capital structure is irrelevant given the existence of a perfect market (without information asymmetry, absence of taxes and other theoretical assumptions). For the authors, the firm's value would be given by the rate of return that it would generate given the risk class of the company and not by the composition of the sources of financing that the entity adopted to generate such returns. Practically, what matters would be the result obtained (returns) and not how this return was financed and obtained (capital structure). Further research has identified a certain relevance to the capital structure, including the authors themselves found relevance to the capital structure if we consider the influence of taxes on the market (Modigliani \& Miller, 1963). Subsequent studies have found evidence in the opposite direction to the proposition of irrelevance, thus proposing new theories to explain decisions about capital structure.

Among these theories, there is the Trade-off theory. This theory predicts that the capital structure is relevant, and that companies seek to reach an optimal point between equity and thirdparty capital. According to this theory, the company would prefer indebtedness (since interest paid on debt could be written off in corporate income tax, benefit from indebtedness) to the point where the cost and risk of new indebtedness would outweigh the benefit of indebtedness. The company will go into debt in order to enjoy the tax benefit of the indebtedness, but from a certain point the costs associated with the additional debt would be higher than the benefit obtained. The Trade-off theory proposes that there is an optimal point of indebtedness, in which the fiscal benefit and the costs of the indebtedness would be balanced. The determination and scope of this optimal point is difficult in practice, especially for small and medium businesses (Buettner, Overesch, Schreiber, \& Wamser, 2012; Correa et al., 2013; Lima et al., 2012; Myers, 1984; Tsuji, 2011).

The Pecking Order, which predicts that instead of the organization seeking to reach an optimal point of indebtedness to balance costs and benefits of indebtedness, in fact companies adjust their capital structure according to a hierarchy of funding sources. This hierarchy is influenced by two issues: financial cost and informational level. First, the company will finance itself with internally generated funds, when these are not enough to finance investment projects, the company will resort to debt, and when the debt is not sufficient, then it will resort to issuing shares (Cotei, Farhat, \& Abugri, 2011; Henrique, Henrique, Soares, \& Silva, 2018; Myers, 1984).

Using the internal funds will not generate any additional financial cost, nor will it imply in a greater disclosure of information to be made use of this type of resource. When the company starts to sue for debt, the financial cost becomes more prominent (since the company will have to pay interest on debt), as well as having to disclose a certain amount of information to capital providers. When the company uses the stock market, the informational cost becomes more prominent, as the entity should have a wide dissemination of information to meet the expectations of potential buyers of shares. In this way, the more profitable a company is, the less it will resort to debt and the issuance of shares, since the funds generated internally would be used to finance the entity (Henrique et al., 2018; Mantezelli, Nobre, Nobre, Sousa, \& Calil, 2017; Myers, 1984; Shyam-Sunder \& Myers, 1999). 
The Market Timing theory works with the idea of windows of opportunity. In this logic, the company would tend to opportunistic behavior based on its knowledge about the real value of its own actions and the value that the market is valuing them. According to this proposition, the company will issue shares when it considers that the price is above its real value (shares over evaluated) and will repurchase them when they are undervalued (Baker \& Wurgler, 2002, 2007; Padilha \& Silva, 2016).

Empirical studies have been using these theories as the main basis for their hypotheses and variables, although other less used theories can be identified that were used to explain the behavior of the capital structure. The theme itself, capital structure, and its macro area, Corporate Finance, are accompanied by a large volume of research at national (Brazil) and international level. Despite this volume, female participation in this production is still restricted (Resende et al., 2012).

\subsection{Female participation in academic production}

Women have always had important contributions in science, just to see the examples in such traditional areas of knowledge: as Hypatia of Alexandria, born between 351/70 with death in 415 (highlighting in Mathematics), Marie Curie (1867-1934, Physics and Chemistry), Virginia Apgar (1909-1975, Medicine), Nise da Silveira (1905-1999, Psychology) and, more current, Celina Turchi (1952-present, Medicine), among many other names. But although there are women researching and doing science, the issue of female participation is still timid in science, being a subject of scientific research.

Historically female participation in science has to face social barriers, marked by machismo. For example, during the fifteenth, sixteenth, and seventeenth centuries, few women exercised important roles as interlocutors and tutors of renowned philosophers and experimentalists. Already in the seventeenth century it was forbidden for them to participate in the discussions that took place in societies and scientific academies throughout Europe. In the eighteenth century, they could have some access to this circle of intellectuals, their access to this activity was mainly due to the family position they occupied: if they were wives or daughters of some man of science could dedicate themselves to the work of support of the science, how to care for collections, cleaning glassware, illustrating and / or translating experiments and texts. Women who produced knowledge in their laboratories assembled in their homes asked that male relatives or another male representative sign as authors of their labors, since knowledge was denied by women. The nineteenth century was marked by the creation of women's colleges, but they remained on the fringes of science. A change in this picture began timidly only after the second half of the twentieth century, when the growing need for human resources for strategic activities such as science, the women's liberation movement and the struggle for equal rights increasing access to scientific education and careers traditionally occupied by men. Currently in the 21st century, women's participation is still restricted and threatened by several more radical and fundamentalist groups, even in the face of so many historical advances in the insertion of women (Alves, 2018; Camargo \& Hayashi, 2017; Leta, 2003; Olinto, 2011; Schiebinger, 2001; Velho \& León, 1988). 
Some factors that contribute to women's lesser access to the scientific environment are the overload of domestic activities, difficulties in reconciling the activities of their profession and those of the partner, the small number of women in decision-making positions, the least amount of authors as renowned researchers in the scientific community. All these barriers are associated with the historical difficulties that have persisted for centuries, in order to make the female gender more 'erased' and dependent on the male gender (Alves, 2018; Olinto, 2011; Rosa \& Quirino, 2016; Soares, 2001). Two mechanisms can be cited to typify the most recurrent difficulties in relation to female access to the academic environment: vertical and horizontal segregation (Figure 1).

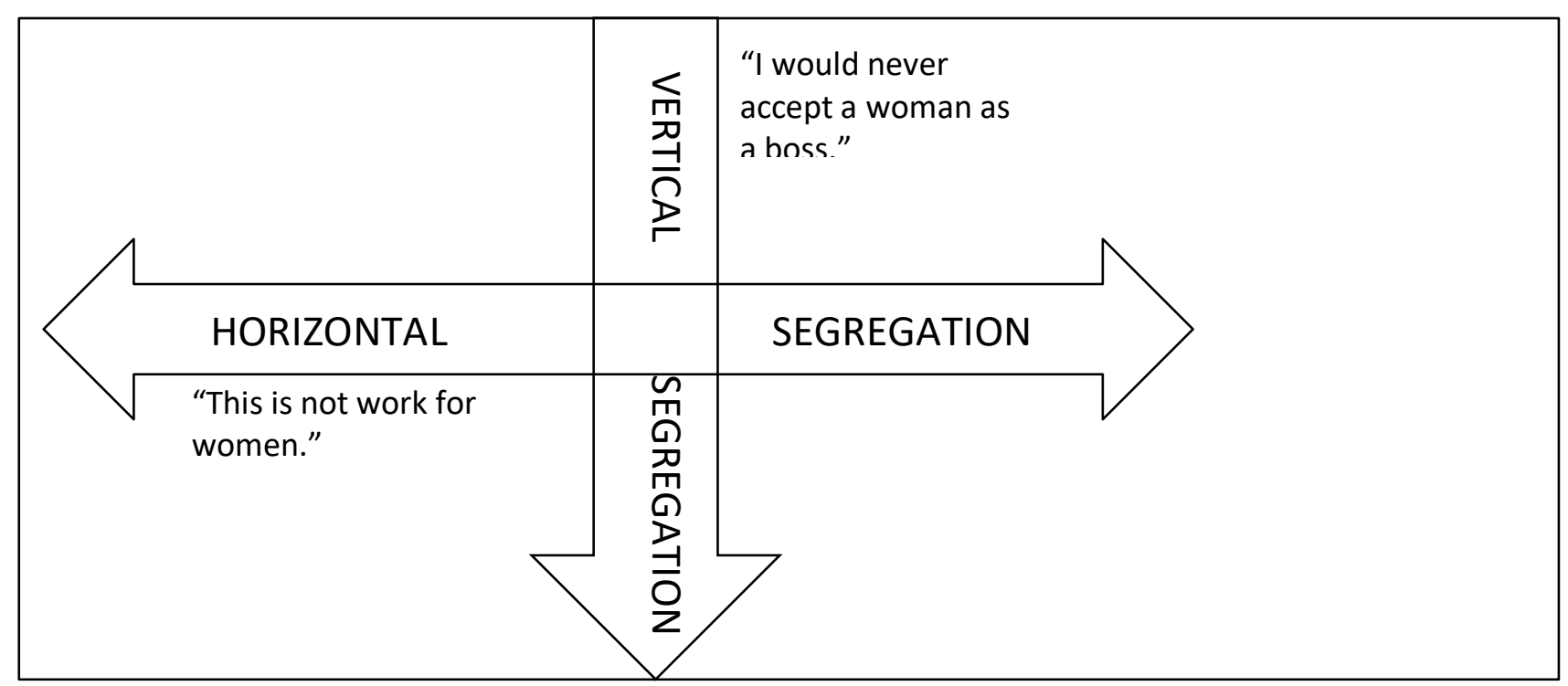

Figure 1: Mechanisms that hamper female participation in science

Source: Elaborated by the authors based on Soares (2001), Olinto (2011) and Alves (2018).

Vertical segregation refers to the barrier in which women can not hold positions of leadership, should remain in subordinate positions or can not progress in the professional choices, thus being at the lower hierarchical levels. This type of segregation is marked by phrases like 'I would never accept a woman as a boss', which indicates a machismo in the professional environment, where women are perceived as incapable of running an organization or who would not do management as well as a man. Some companies and organizations raise the flag against this segregation by enabling women to be chief executive officers of organizations (CEO), to reach positions of political leaders, among other leadership positions that historically are reserved for men (example, only in 1932 women had the right to vote in Brazil) (Alves, 2018; Olinto, 2011; Rosa \& Quirino, 2016).

Horizontal segregation, on the other hand, deals with the social barrier in which access to certain functions is prohibited for women, they are led to make choices different from those made by men. This kind of segregation is visible in phrases such as 'this is not work for a woman'. So some functions are reserved for men (scientist, politician, businessman, manager, intellectual and others) and women (secretary, teacher of children's education, domestic, manicure and others). This influence on the choices of the activities is due, for example, to the family and school performance that leads the girls to evaluate themselves as more suitable for the exercise of certain activities and, 
therefore, to establish for themselves more adequate life strategies with what they consider, or are taken to consider, as more compatible to them. In this way, horizontal segregation is the term used to indicate the segregation of women and men in different types of activity (Alves, 2018; Olinto, 2011; Rosa \& Quirino, 2016). This segregation of jobs and activities around the world, based on the idea that there must be a distinction between the work that must be performed by women and those reserved for men, is called the principle of separation (Hirata, 2018).

Santos et al. (2016), in her study on the barriers of recognition of mining entrepreneurs, mentions that these barriers can also be known by other terms. These terms are: glass ceiling that will correspond to vertical segregation (difficulty faced by women seeking to achieve higher positions in the organizational hierarchy) and glass wall which is equivalent to horizontal segregation (difficulty of women who already occupy leadership positions, but who want recognition for their efforts). The values that permeate the 'glass roof' barrier are associated with women's opinions (are the dominant ones) and those associated with men's opinions about the characteristics of women.

The female historically has a greater difficulty in entering scientific means because of the horizontal segregation in which the work of scientist would be considered as 'activity reserved for men'. For example, Bernd, Anzilago e Beuren (2017) which show that between 2010 and 2016 the number of women who entered the postgraduate programs in Accounting Sciences was lower (36\% of all students) than men (64\%). As well as the issue of vertical segregation, where women can act in science, they find less opportunities to support and publicize their productions. For example, Guedes, Azevedo e Ferreira (2015) which indicate that between 2001 and 2012, the number of productivity grants of the National Council for Scientific and Technological Development (CNPq), in the various areas of knowledge, were largely distributed to men.

The scientific literature has identified that female participation in scientific production is lower than male participation. This indicates that researchers have difficulty participating more in the production of knowledge, as well as indicates that patriarchy prevails, even in the field of science (Alves, 2018; Cabral, 2015; Cunha et al., 2014; Leta, 2003; Lino \& Mayorga, 2016; Olinto, 2011). It is fundamental to disagree with the stereotyped argument and attitudes that reinforce the idea that there are differentiated skills or roles and sectors of specific actions to be performed between men and women as a natural (Guimarães \& Silva, 2015; Rosa \& Quirino, 2016).

\subsection{Previous studies}

Bibliometry is a technique of analyzing the characteristics of scientific production using mathematical or statistical analyzes (Pritchard, 1969). It refers to the statistical tool that allows the mapping and creation of indicators for the treatment and administration of information, as well as the analysis of means of scientific dissemination and productivity of a given community and scientific network (Chueke \& Amatucci, 2015). Therefore, bibliometrics is used to analyze the characteristics of scientific production (number of articles produced, gender of the authors, type of references used, quality of periodicals in which articles were published, authors' productivity and others) by theme, means of dissemination, period, authorship or other stratification. 
Some bibliometric studies were developed in order to investigate female participation in academic production in the fields of science. For example, Morais et al. (2018) analyzed the female participation in 1,724 articles published by 23 periodicals classified as $A 1$ to $B 2$, in the areas of Administration and Accounting Sciences, in the triennium from 2013 to 2015, according to the QualisCapes system. The analysis was through bibliometrics verifying the female participation in front of the male, the historical evolution (or involution) of this participation and the authors who produced the most. The results indicated that the female participation (37.33\%) is still lower than the male participation (62.67\%); historically female participation did not change; the surveys are mostly qualitative; the most prolific authors are doctors, mostly from the South and Southeast regions of Brazil and linked to public institutions.

Leite, Oliveira and Frutuoso (2018) carried out a bibliometric study on the participation of women in Mineral Technology, through the National Meeting on the Treatment of Minerals and Extractive Metallurgy from its origin (1973) until 2015. The results indicated that the pioneer researcher at the congress was Profa. Hedda Vargas Figueira (CETEM and UFRJ) who published two articles in 1973. During the period analyzed, female participation did not exist in 1976, but has been surpassing male participation since 2007 (despite this growth in participation, the authors warn that women are not characterized as leading researchers). The most prominent researcher in this period is Profa. Virginia Sampaio Teixeira Ciminelli (UFMG), with relevant works in the area of hydrometallurgy. There has also been an increase in publications of articles involving only women. The work shows strong feminine insertion in science in the area of mineral technology. The results found by the authors (for this event) are divergent from the authors' findings for other areas, being therefore indicative that some areas and events are a more propitious space for female scientific production.

Resende et al. (2012) (2000-2001). In this paper, the authors analyzed the participation of women in a bibliometric study in 506 articles from the Finance area of the Anpad Meeting (EnANPAD's) between 2000-2010. The findings indicated a lower female participation (only 27 articles of female authorship and 184 articles of mixed authorship). The area in which the authors most published work was that of Corporate Finance and the area that men had the greatest participation was the Financial and Capital Markets. The authors who published the most are institutions based in the South and Southeast regions of Brazil.

De Luca et al. (2011) studied women's participation through bibliometrics in 1,294 articles published in the Meetings of the National Association of Postgraduate and Research in Administration (EnANPAD), the USP Congresses of Controllership and Accounting and the National Association of Post-Graduate Programs in Accounting Sciences (ANPCONT) between 2004 and 2009 (for the first two congresses) and 2007 to 2009 (for the last congress). Female participation was found in 755 articles (58.33\%) of the articles, of which only 97 (7.50\%) were exclusively female authors. The growth of the relative participation of women usually accompanies that of the total number of authors, and in recent years there has been a decrease in this participation in the events of USP and ANPAD, and an increase in ANPCONT. The majority of female authors are authors from the Brazilian regions Southeast (45.5\%) and South (26.2\%). The authors conclude that the study 
revealed that the difference between men and women in production is clear and perceptible in the papers published in the area of Accounting in the analyzed events.

Ramos and Tedeschi (2015) investigated the female participation in the Institute of Biosciences (IB) and the Institute of Geosciences and Exact Sciences (IGCE) of UNESP, Campus Rio Claro. In the IB the female participation in the departments of the institute was on average $49.22 \%$ of the teachers, the department with the lowest female participation in Zoology (10\% of the teachers), the authors add that this area is considered as high prestige; the Departments of Biology and Physical Education were the most egalitarian $(56.25 \%$ and $51.72 \%$, composed of women, respectively). In addition to all IB teachers, they represent $49.22 \%$ of teachers, but only $46.27 \%$ of scientific production. In the IGCE, the female participation in the departments was, on average, 39.42\%. The lowest female participation was in the Department of Petrology and Metalogy (10\%), the highest was DEPLAN (55.56\%). Although women represent almost $40 \%$ of teachers, the concentration of female production was $26.88 \%$. These results call attention to the discrepancy in the number of authors and their scientific production. One of the effects that may aggravate this situation is the 'Matilda', in which women give up the coordination of research groups to men with higher titling in order to guarantee the obtaining of resources for research.

Another way to verify female participation in scientific production is the question of the authors' contribution to the paper. It should be noted that such studies are more difficult to perform, since the journal or journal itself would have to require this type of disclosure by the authors. Macaluso, Larivière, Sugimoto and Sugimoto (2016) carried out a study of this type. The research was only possible because the consulted database, the Public Library of Science (PLOS), requires each author to indicate their contribution to the work to be published, and this contribution refers to at least one of the following tasks: (1) (2) designed and designed the experiments, (3) contributed reagents / materials / analysis tools, (4) performed the experiments and (5) wrote the paper. After analyzing 85,000 articles published between 2008 and 2013 in PLOS journals, from the descriptive and regression analyzes, the authors were able to identify how the female contribution occurred in the production of these articles. The authors observed that women were significantly more likely to be associated with experiencing, and men were more likely to be associated with all other authoring roles. Finally, the researchers point out that the requirement of the authors' contribution to research is an act of transparency, allowing an equitable allocation of funding for research, as well as the recognition of researchers, since some researchers, especially young people and women, they develop the most significant part of the work, but do not obtain greater recognition, financing or responsibility.

Initiatives to give greater visibility to the works produced by researchers are being developed. As in the work of Machado, Souza and Mello-Carpes (2018) who performed a presentation of the production carried out by women in the city of Uruguaiana (Rio Grande do Sul, RS) to two groups of students (49 students aged 15 to 18 and 42 students of the same age group). The first group was asked before the presentation if they would be able to name any scientist, since she was a woman, only 2 students ( $4 \%$ of the 49 students) answered the question. After a round of talks with three researchers, the students who were able to answer the question rose to $84 \%$, indicating that perhaps the students did not have a discernment of what could be considered as 
Science to name a scientist, even knowing the name of a researcher. The second group was taken to visit some laboratories of the researchers, the students assigned a grade of nine for the visitation proposal of the laboratories to know the work of researchers. These findings indicate that female participation is not as visible to this young audience (even in the case of surveys conducted near the city in which they study), and that the initiative to develop women's work was well accepted, indicating that the experience should be applied in other institutions.

In addition to the studies that essentially carried out studies on female participation, other bibliometric studies have finally identified that female participation is still restricted in their research areas. For example, Greenbaum (2018) on scientific production of the most productive authors authors, editors and editorial board members of five educational psychology journals (Cognition and Instruction, Contemporary Educational Psychology, Educational Psychology, and Journal of Educational Psychology) from 2009 to 2016. Souza et al. (2017) on Finance published in the Revista de Administração de Empresas (RAE), from 2006 to 2016. Cavero et al. (2015) on female evolution in computer publications, from 1936 to 2010, available digital library and library project database (DBLP). Amaral et al. (2014) on the Financial Market of Credit and Capital in the Congressos USP de Controladoria e Contabilidade and ANPCONT from 2007 to 2011. Araújo et al. (2014) on the accounting skills of the national electronic journals of Accounting Sciences. De Luca et al. (2014) on the theme of sustainability in research at the Anpad Meeting (2003-2010) and in Revista de Gestão Social e Ambiental (2007-2010). Souza et al. (2014) on the profile and scientific production of the researchers of the area of Periodontics, in which they were consulted to the curriculum Lattes of all the scholars scholars of productivity in the area of Dentistry, referring to the 2011/2012 biennium. Among the authors who found a greater female participation, it is mentioned Joly, Bustamante and Oliveira (2015) on cross-cultural studies in Psychological Assessment, from 1992 to 2010; and Oliveira, Pereira and Gaspar (2014) on Environmental Management in the Brazilian sugarcane sector in the annals of four events (EnApad, ENGEMA, SEMEAD and SIMPOI), from 2008 to 2012.

The controversial results between the areas indicate that more research is needed on female participation, especially in the areas not yet investigated within these areas, such as the capital structure. The financial area is known as an area where most researchers (including researchers who excel at academia) are men, so analyzing this question can help understand how gender participation is shaped. Among the themes of corporate finance, the capital structure was highlighted by its volume of research and the development of several theories. Therefore, this paper proposes to investigate the female participation within the thematic of capital structure in articles published in Brazil.

\section{METHODOLOGY}

\subsection{Search Characterization}

As for the methodological aspects, scientific research is commonly classified as regards the (i) problem, (ii) objective, and (iii) designs. Regarding the objective, this research is descriptive. Descriptive studies aim to describe or register characteristics of a phenomenon, without interfering 
with it (Prodanov \& Freitas, 2013). In this research, the characteristics of female production in capital structure are analyzed, such as the relative participation of women in production, the geographical distribution of this production, the history analysis of (in) evolution of this participation and others.

In the case of the problem, this study is of the qualitative-quantitative type. Quantitative research is marked by the use of statistical techniques (from more basic techniques, such as descriptive statistics, to more robust techniques such as regression models), in turn, qualitative research is recognized for performing readings and interpretations of social realities. The combination of these two types of research has the advantage of broadening the view on the problem investigated, allowing a deeper analysis (Souza \& Kerbauy, 2017). For the analysis of female participation, this research uses descriptive statistics, and also uses a description of the qualitative aspects, in particular, the implications of the characteristics of this participation in light of the barriers of horizontal and vertical segregation, within from the perspective of the difficulty of the woman to become a scientist and gain prestige, given the patriarchalism in Science.

Regarding the research design (how the research design will be developed), this work is used in bibliographical research (Gil, 2014). In this work a survey of the scientific articles published in the Brazilian journals on capital structure is carried out, in order to verify the female participation in the academic production on the subject. Bibliometrics is used at this stage of documentary analysis (Chueke \& Amatucci, 2015; Pritchard, 1969; Quevedo-Silva, Santos, Brandão, \& Vils, 2016; Vanti, 2002).

\subsection{Characterization of the analysis and sample}

The analysis of the articles collected will be carried out through the use of bibliometrics. By bibliometrics, it is understood that it is an application of statistical methods and mathematics for books and other means of communication, such as publications in scientific articles (Pritchard, 1969). In bibliometric studies, it is common that research tends to focus on the production of articles in a given field of knowledge, mapping the academic communities, identifying networks of researchers, production in scientific journals or checking the validity of classical bibliometric Laws, such as Lotka's Law (Alves \& Crisóstomo, 2018; Chueke \& Amatucci, 2015; Chung \& Cox, 1990; Ribeiro \& Costa, 2013; Sánchez-Perdomo, Rosario-Sierra, Herrera-Vallejera, Rodríguez-Sánchez, \& Carrillo-Calvet, 2017; Serrano, 2018).

The Capes/MEC, SciELO and SPELL Journal Portals databases were consulted on 11/28/2018, so that all articles published up to that date were available. The choice of these bases was due to the fact that more Brazilian articles are available in them (the Portal de Periódicos is under the authority of Capes, which is an organ of the Brazilian federal government; SciELO is a project of the Fundação de Amparo à Pesquisa do Estado de São Paulo (FAPESP) and SPELL is linked to the Associação Nacional da Pós-Graduação e Pesquisa em Administração AnPad) and the Instituto Brasileiro de Estudos e Pesquisa Social (IBEPES)). This indicates that these bases agglutinate more Brazilian articles, unlike other bases that only index articles in English (which considerably reduces 
the probability of obtaining a greater amount of Brazilian articles on capital structure). Figure 2 summarizes the flow of bibliometric analysis used in the research.

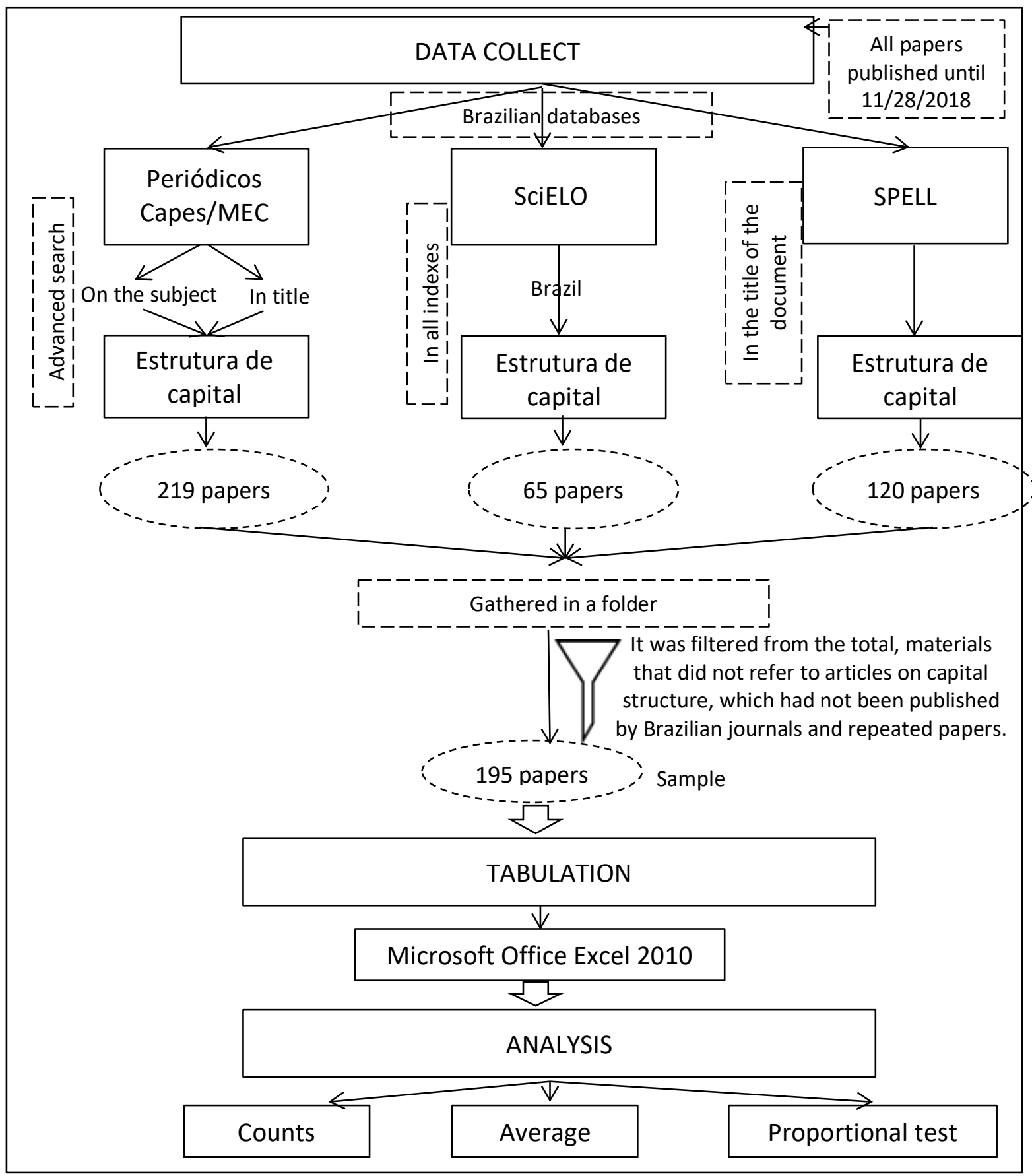

Figure 2: Bibliometric flow in the collection and analysis of the research Source: Prepared by the authors (2019).

When accessing the Journal Portal page, the Advanced Search tool was clicked. In the loaded screen, to search the articles on the expression "Estrutura de capital", two filters were used: search in the subject and search in the title. In the SciELO page, we searched for the same expression, "Estrutura de capital", but the search was defined in the filter 'in all indexes', restricting the country of publication to Brazil. In SPELL, the search was done with the expression "Estrutura de capital"in 
the title of the document. The choice of these databases was given as the main agglutination of national scientific articles, in addition to enabling the use of filters to obtain the largest amount of articles related to the subject of capital structure.

From the total of 404 results presented for the searches in the databases $(219,65$ and 120 results) returned in the searches in the Portal of Capes/MEC, SciELO and SPELL, respectively), a nonprobabilistic sample of 195 scientific articles was obtained (excluding those materials that were not scientific papers, which were not published by national journals, those that did not refer to the subject of capital structure and repeated articles).

The data of the articles were tabulated in the software Excel 2010. After the tabulation, the data were analyzed through counts and averages of the frequencies of the information. From the results data sheet, the following information was analyzed: (i) relative female participation in the sample; (ii) (in) historical evolution of female participation; (iii) the average participation of the genres in the number of authors per article; (iv) the most productive authors; (v) the gender of the most productive authors; (vi) the titration of the authors by gender; (vii) the most representative institutions, (viii) the gender distribution of the participation of authors of these institutions and (ix) the participation of women in the aspect of the authors' regionality of provenance. In the following section the results of the research are presented, through the presentation of graphs, tables and more detailed descriptions of aspects of the characteristics of the articles, besides presenting a discussion thereof; in addition to gender and gender ratio tests, to verify if there is actually statistical difference between the genres (tests performed in the STATA 12 software).

\section{RESULTS AND DISCUSSION}

In order to analyze the female participation in the scientific production on capital structure, published by Brazilian journals indexed to the databases informed in the methodology, this work was developed based on a bibliometric analysis of a non-probabilistic sample of 195 articles. From the search carried out in the three databases, 195 scientific articles were published, published by 66 journals, which were produced by 412 authors from 97 different affiliation institutions. A total of 566 authors were observed. The amount of authorship is greater than the number of authors because the same author can be a participant in more than one article, therefore he is contact as an author, but for each participation in a paper will be counted as an author.

These articles were published in Brazilian journals classified in the QualisCapes system, with most of these journals being classified in the highest strata of QualisCapes: A2 with 54 articles or, in percentage, $28 \%$ of the sample; B1 with 62 articles or 32\%; B2 with 39 articles or 20\%; B3 with 35 articles, $20 \%$ of the sample. Periodicals with lower strata had few publications on the subject (B4 with 4 articles or $2 \%$ and B5 with 1 article or $1 \%$ ). The three highest strata (A2, B1 and B2) accounted for $79 \%$ of all production on the topic, this indicates that the theme is considered relevant to the journals considered of higher quality in the QualisCapes system. The female participation of the sample (counted from the authorship) is shown in Figure 3. 


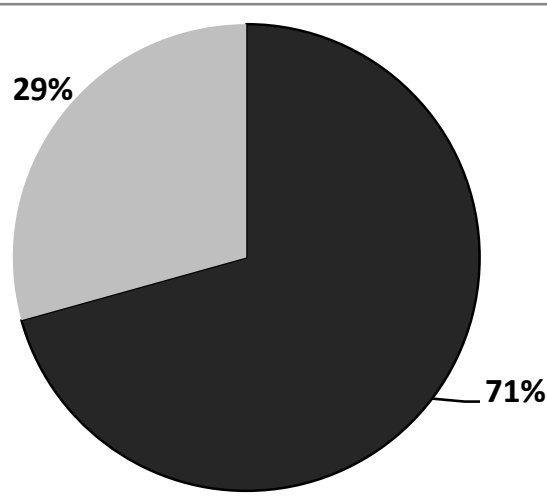

male

female

Figure 3: Female participation

Source: Prepared by the authors (2019).

It is observed that the authors' participation ( $29 \%$ or 166 female authors) in articles is smaller than that of men (71\% or 400 male authors). This result already calls attention to the issue of female participation being restricted in academic production on capital structure. This result corroborates with other works developed within the macro area of Finance, such as Souza et al. (2017) and Amaral et al. (2014). The behavior of the genres, historically, is evidenced in Figure 4

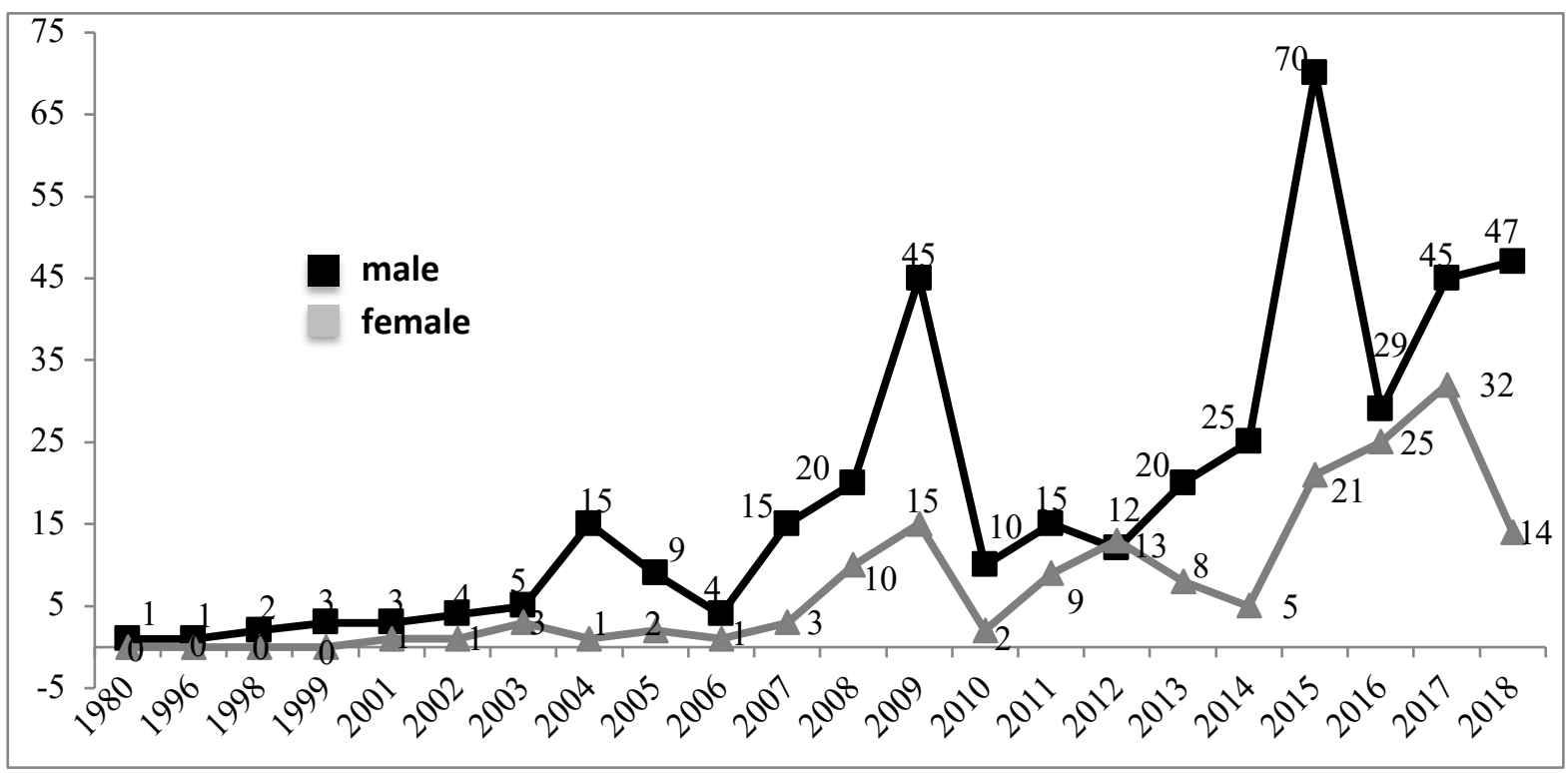

Figure 4: Historical analysis of the participation of the genres

Source: Prepared by the authors (2019).

Historically (1980-2018), men have a greater participation in published works; except in the year 2012, when the women (13 authors) surpassed the number of men (12) by authorship. The proportion test (Pearson chi2 $(21)=36.7559)$ indicated that the gender participation over the years analyzed is actually statistically different $(P$-value $=0.018)$ between men and women. This finding indicates that in addition to men occupying the largest space in the production of knowledge about capital structure, they have always been occupying this space. Because it is a traditional and established knowledge within the field of Corporate Finance (with relevant seminal works that permeate until the 1950s), and historically it is being produced by men, it is not by chance the least female participation, since it is a complex theme and marked by prominent authors who are men. 
Regarding this question of the prominence of some men, it was identified that they were the authors who produced the most articles (Table 1).

Table 1: Most prolific authors

\begin{tabular}{lll}
\hline Authors & Gender & Number of articles \\
\hline Wilson Toshiro Nakamura & Male & 18 \\
Eduardo Kazuo Kayo & Male & 8 \\
Tatiana Albanez & Female & 8 \\
Mauricio Ribeiro do Valle & Male & 8 \\
Joséte Florêncio dos Santos & Female & 6 \\
Fernanda Finotti Cordeiro Perobelli & Female & 5 \\
Leonardo Fernando Cruz Basso & Male & 5 \\
Paulo Renato Soares Terra & Male & 5 \\
\hline TOTAL & & 63 \\
\hline
\end{tabular}

Source: Prepared by the authors (2019).

It is observed that of the eight most prolific authors, only three are women (and all three are highly educated, having a doctoral degree), whether they are prof. Tatiana Albanez (produced eight articles, contesting the second most productive author with Prof. Eduardo Kazuo Kayo and Prof Mauricio Ribeiro do Valle), Profa. Josete Florêncio dos Santos (with six articles) and Profa. Fernanda Finotti Cordeiro Perobelli (with five articles, same amount of professors Leonardo Fernando Cruz Basso and Paulo Renato Soares Terra). The most prolific author was Prof. Wilson Toshiro Nakamura (with 18 articles), result corroborates with the work of Nakamura, Jones and Nakamura (2017) and Alves and Crisóstomo (2018).

One argument put forward regarding the authors who do not possess a high academic formation, based on vertical segregation, would be that for the women to obtain greater approval of their articles, they would invite men of greater formation to be coauthor in their papers. An alternative question is tied to the guideline-oriented relationship, where normally the most qualified teachers and who research more about capital structure are men, being common women who produce enough along with their supervisors (Alves, 2018; Cabral, 2015; Camargo \& Hayashi, 2017; Lino \& Mayorga, 2016; Mello, Crubellate, \& Rossoni, 2009; Olinto, 2011). Despite this point, Table 2 shows the participation of the genres distributed in the number of authors per article.

Table 2: Mean participation of the genres in the number of authors per article

\begin{tabular}{cccc}
\hline Number of authors per paper & Male & Female & Women's participation \\
\hline 1 & 10 & 3 & $23 \%$ \\
2 & 103 & 29 & $22 \%$ \\
3 & 133 & 50 & $27 \%$ \\
4 & 97 & 59 & $38 \%$ \\
5 & 46 & 24 & $34 \%$ \\
6 & 11 & 1 & $8 \%$ \\
\hline TOTAL & 400 & 166 & $29 \%$
\end{tabular}

Source: Prepared by the authors (2019). 
This result indicates that a larger number of authors per article opens the possibility of greater female participation or in another interpretation. Although the findings indicate that both men and women prefer to publish in partnership (with two or more authors per article), women have a greater participation when the articles have more authors (articles with three authors had in their role of authors , $27 \%$ as women, $38 \%$ in the articles with four authors, and $34 \%$ in the articles with five authors). The exception of this situation was verified in the only two articles that had six authors each, in which only one woman had participation among the 12 authors (Table 3).

Table 3: Titration of authors by gender

\begin{tabular}{lccc}
\hline Titration & Male & Female & Women's participation \\
\hline Uninformed & 124 & 41 & $25 \%$ \\
Bachelor's Degree & 1 & 8 & $89 \%$ \\
Bachelor & 11 & 12 & $52 \%$ \\
Specialist & 2 & 4 & $67 \%$ \\
Studying masters & 12 & 11 & $48 \%$ \\
Master & 47 & 27 & $36 \%$ \\
Studying doctorate & 46 & 24 & $34 \%$ \\
Doctor & 140 & 38 & $21 \%$ \\
Post doctor & 17 & 1 & $6 \%$ \\
\hline Total & 400 & 166 & $29 \%$ \\
\hline
\end{tabular}

Source: Prepared by the authors (2019).

Although Table 3 is not a conclusive indicator, it provides more support for the argument in vertical segregation, that even women who are able to enter Science find it difficult to publish their research individually and end up inviting men of higher qualification to participate in your articles. It is observed that the highest degrees are composed less and less by women (the authors who declared in the articles as holders of the titles of Doctor and Postdoctor are equivalent to $21 \%$ and $6 \%$, respectively, of the number of authors with this degree). The proportion test (Pearson chi2 (8) $=43.6616)$ indicated that there is a statistically significant difference ( $P$-value $=0.0000)$ for titration between the genres, confirming that the higher titers actually have a higher male presence and the women prevailed for women.

Although this finding may support the argument for female dependence due to the lower number of authors with the highest degree, two initial points have to be analyzed prudentially: (1) there are 165 authors who did not declare a title in articles and (2) there is a question of the guidingorientandas relationship, in which a course-completion work may have been published as an article, and not necessarily that the woman alone produced the article and invited a man just for having a higher degree and recognition in the scientific academy. But in any case, this finding contributes to the discussion of women's access to higher education, since a series of situations makes this access difficult, characterizing the horizontal segregation barrier. Next, we identify the institutions of affiliation of authors of greater prominence in the scientific production on capital structure (Table 4). 
Table 4: Distribution by gender of the participation of the most representative institutions

\begin{tabular}{lccc}
\hline Institution of the author & Male & Female & Women's participation \\
\hline USP & 60 & 15 & $20 \%$ \\
Mackenzie & 52 & 3 & $5 \%$ \\
FURB & 26 & 18 & $41 \%$ \\
UFMG & 24 & 11 & $31 \%$ \\
FGV & 19 & 5 & $21 \%$ \\
UFU & 9 & 10 & $53 \%$ \\
UFC & 10 & 6 & $38 \%$ \\
PUC-PR & 9 & 6 & $40 \%$ \\
UFSC & 11 & 3 & $21 \%$ \\
UFSM & 2 & 12 & $86 \%$ \\
UnB & 12 & 2 & $14 \%$ \\
\hline Total & 234 & 91 & $28 \%$ \\
\hline
\end{tabular}

Source: Prepared by the authors (2019).

The three most representative institutions in the sample are located in the Southeast region of Brazil, the Universidade de São Paulo (USP, with 75 authors in the sample), the Universidade Presbiteriana Mackenzie (Mackenzie, 52) and the Fundação Universidade Regional de Blumenau (FURB, 26), together with the other eight most representative institutions, concentrated $28 \%$ of all authorship of articles published in Brazil on capital structure.

In terms of female participation, only female participation (10 and 12 authors, respectively) surpasses the male participation in the Universidade Federal de Uberlândia (UFU) and the Universidade Federal de Santa Maria (UFSM). These most representative institutions are located in the South and Southeast regions of Brazil, with the exception of the Universidade Federal do Ceará (UFC), located in the Northeast region of Brazil and the Universidade de Brasília (UnB), which is located in the Center-West region (Figure 5).

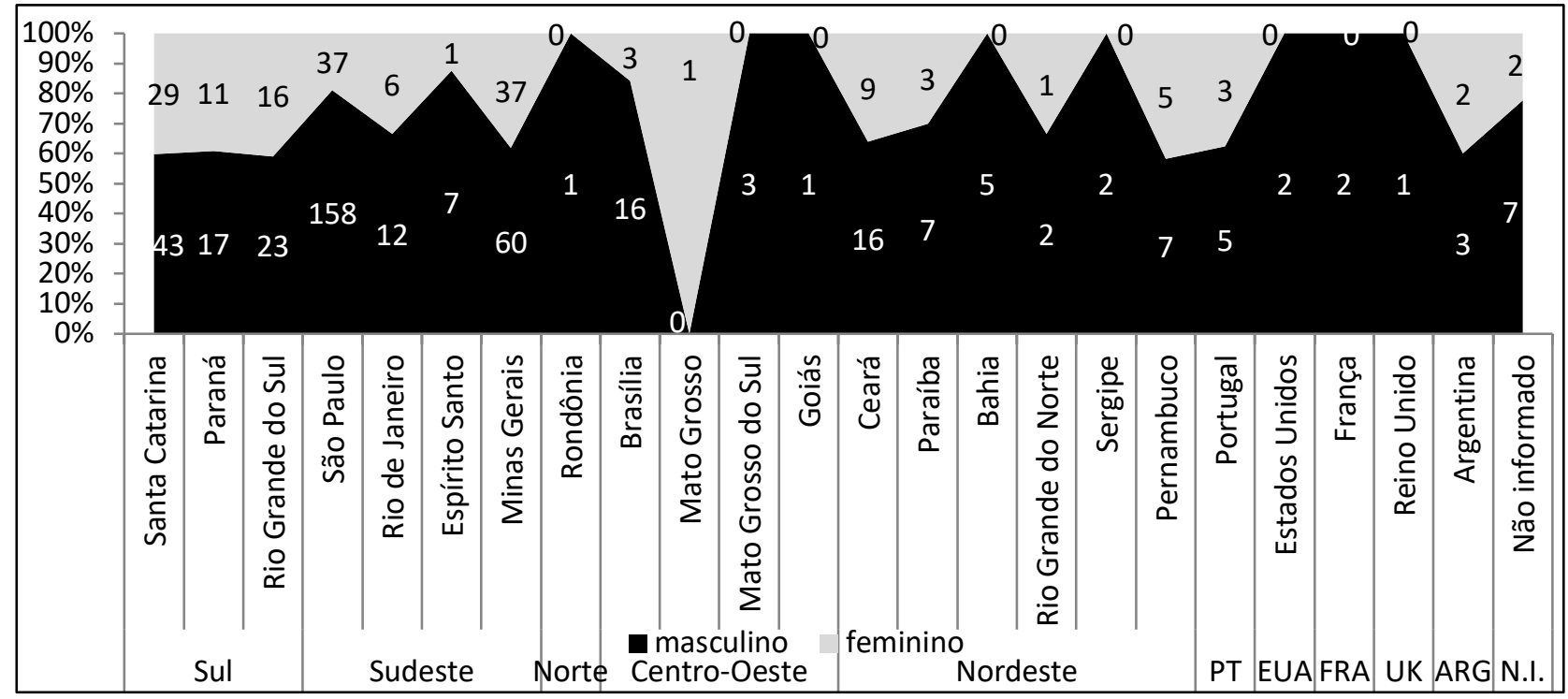

Figure 5: Regionality of author by gender of the author

Note: PT refers to Portugal; EUA refers to the United States; FRA refers to France; UK refers to the United Kingdom; ARG refers to Argentina; N.I. refers to authors who did not indicate their region of provenance in the articles.

Source: Prepared by the authors (2019). 
Although the articles have been published only by Brazilian journals, it is observed that some foreign authors published their works in Brazilian journals, however, this participation of foreign authors is timid (3\% of all authors) compared to the participation of Brazilian authors . In any case, male participation (black area in Chart 3) is greater than female participation (gray area) in all regions, except in the Brazilian state of Mato Grosso, where the only article with author's participation in that state was written by a woman. The extremes (in which the male participation was $100 \%$ ) were the Brazilian states of Rondônia (only one author from that state with participation in publication in the sample, and was a man), Mato Grosso do Sul (three authors from that state), Goiás (one author), Bahia (five authors), Sergipe (two authors), and in the contributions of authors from the following countries: the United States ( 2 authors), France ( 2 authors) and United Kingdom (one authorship). The geographical region in which male and female participation will reach closer to the point of balance (closer to $50 \%$ for both) was Pernambuco (female participation was $42 \%$ and male participation was $48 \%$ ). The proportion test (Pearson chi2 $(10)=14.8438$ ) indicated that, in fact, there is a statistically significant difference $(P$-value $=0.938)$ between the genres in the aspect of regionality.

The findings of the research corroborate previous studies that identified, in the areas under analysis, a lower female participation (Amaral et al., 2014; Araújo et al., 2014; De Luca et al., 2014; Morais et al., 2018; Resende et al., 2012; R. M. F. de Souza et al., 2017; J. G. S. Souza et al., 2014). In addition to the difficulties associated with entering higher education and academic progress in obtaining degrees, there are those related to barriers linked to the lesser possibility of production. Mechanisms of vertical and horizontal segregation can also be identified indications of these when analyzing the scientific production on capital structure in national journals.

\section{CONCLUSION}

This paper aims to analyze the female participation in the scientific production on capital structure in Brazilian periodicals. A bibliometric study of this participation was carried out in 195 scientific articles, written by 412 different authors, with an average of three authors per article, being published by 66 journals between 1980 and 2018. The bibliometric analysis verified characteristics of the works as the female participation in the sample, the historical analysis of this participation, the most prolific authors, the most representative affiliation institutions, and the regionality aspect.

The objective of the study was reached, since the research findings make it possible to know the female participation in production on the subject capital structure. The main findings were that female participation is lower than male participation ( $29 \%$ of authors are female), that historically female participation has always been lower (except for 2012), which authors prefer to publish in (the fact that the greater number of authors per article provided the greater participation of women than in articles with fewer authors).

In addition, of the eight most productive authors, only three are women (all with a high academic background). Although the three most prolific women have high titers, this reality does not correspond to the others in the sample, in fact, it is observed that among the authors with high 
education few are women, and of the authors with less titration, there are more women. In the case of educational institutions, three of them concentrate $31 \%$ of the participation in articles produced on capital structure. Female participation was higher than male participation in only two of the eleven most representative institutions. Even in the geographic distribution, there is a male participation that surpasses the feminine (there are only a few regions, less representative in terms of the number of authorships, in which the female gender prevailed).

As a suggestion for future work, it is indicated the enlargement of the sample for, besides the articles of periodicals, for the works published in events and the works of conclusion of course. A study comparing production on capital structure, by gender, between countries can be developed. As the sample is expanded to other modes of publication of scientific papers, it is advisable to use more robust statistical techniques, such as regression models.

The findings of this article are not intended to promote a sense of war between the genres, but in fact, enable an analysis of female participation in scientific production, in addition to other articles from other areas that raise this issue. Initially, the study draws attention to the issue of women's entry, permanence and completion of higher education, then to women's progression towards higher qualifications and to greater participation in the production of scientific knowledge. In addition, the findings support the assumptions of vertical and horizontal segregation, according to the discursive results.

\section{REFERENCES}

Alves, F. I. A. B. (2018). Uma análise da participação feminina na produção em um periódico internacional de economia. Ciências Sociais Em Perspectiva, 17(33), 115-136. Retrieved from https://bit.ly/2SvXAJh

Alves, F. I. A. B., \& Crisóstomo, V. L. (2018). Perfil da pesquisa em estrutura de capital no Brasil. Revista Observatorio de La Economía Latinoamericana, 2018(8), 1-16. Retrieved from https://bit.ly/2KBcdYK

Amaral, M. R. do, Santana, C. M., Sales, I. C. H., \& Neto, L. M. de A. (2014). Perfil dos autores na produção científica em mercado financeiro de crédito e de capitais nos congressos USP de controladoria e contabilidade e congresso ANPCONT. Revista Evidenciação Contábil \& Finanças, 2(2), 55-68. Retrieved from https://bit.ly/2PkoP7m

Araújo, J. G. N. de, Meira, J. M. de, Lopes, L. da C., Medeiros, P. M. de, \& Soeiro, T. de M. (2014). Um estudo bibliométrico sobre as características dos artigos de perícia contábil dos periódicos eletrônicos nacionais de acesso gratuito de Ciências Contábeis. Revista de Gestão e Contabilidade Da UFPI, 1(2), 23-41. Retrieved from https://bit.ly/2UeqUWf

Baker, M., \& Wurgler, J. (2002). Market timing and capital structure. The Journal of Finance, 57(1), 1-32. Retrieved from https://goo.gl/4cCyrZ

Baker, M., \& Wurgler, J. (2007). Investor Sentiment in the Stock Market. Journal of Economic Perspectives, 21(2), 129-151. https://doi.org/10.1257/jep.21.2.129 
Bernd, D. C., Anzilago, M., \& Beuren, I. M. (2017). Presença do gênero feminino entre os discentes dos Programas de Pós-Graduação de Ciências Contábeis no Brasil. Revista de Educação e Pesquisa Em Contabilidade, 11(4), 408-429. Retrieved from https://bit.ly/2PiFisT

Buettner, T., Overesch, M., Schreiber, U., \& Wamser, G. (2012). The impact of thin-capitalization rules on the capital structure of multinational firms. Journal of Public Economics, 96(1), 930938. Retrieved from https://bit.ly/2InoT3M

Cabral, C. (2015). Os estudos feministas da ciência e da tecnologia no Brasil: reflexões sobre estilos e coletivos de pensamento. Revista Ártemis, 20(1), 76-91. Retrieved from https://goo.gl/4BoKuo

Camargo, J. R. F. de, \& Hayashi, M. C. P. I. (2017). Coautoria e participação feminina em periódicos Brasileiros da área de cirurgia: Estudo bibliométrico. Revista Digital Biblioteconomia e Ciência Da Informação, 15(1), 148-170. Retrieved from https://bit.ly/2E1JII1

Cavero, J. M., Vela, B., Cáceres, P., Cuesta, C., \& Sierra-Alonso, A. (2015). The evolution of female authorship in computing research. Scientometrics, 103(1), 85-100. Retrieved from https://link.springer.com/article/10.1007/s11192-014-1520-3

Chueke, G. V., \& Amatucci, M. (2015). O que é bibliometria? Uma introdução ao Fórum. Revista Eletrônica de Negócios Internacionais, 10(2), 1-5. Retrieved from http://internext.espm.br/index.php/internext/article/view/330

Chung, K. H., \& Cox, R. A. K. (1990). Patterns of productivity in the finance literature: a study of the bibliometric distributions. The Journal of Finance, 45(1), 301-309. Retrieved from https://www.jstor.org/stable/2328824?seq=1\#page_scan_tab_contents

Correa, C. A., Basso, L. F. C., \& Nakamura, W. T. (2013). A estrutura de capital das maiores empresas brasileiras: análise empírica das teorias de pecking order e trade-off, usando panel data. Revista de Administração Mackenzie, 14(4), 106-133. Retrieved from https://goo.gl/gn1Fba

Cotei, C., Farhat, J., \& Abugri, B. A. (2011). Testing trade-off and pecking order models of capital structure: does legal system matter? Managerial Finance, 37(8), 715-735. Retrieved from https://bit.ly/2HA4VX3

Crisóstomo, V. L. (2011). Inversión, restricción financiera y estructura de propiedad en Brasil (1st ed.). Saarbrücken: Editorial Académica Española.

Cunha, M. B. da, Peres, O. M. R., Giordan, M., Bertoldo, R. R., Marques, G. de Q., \& Duncke, A. C. (2014). As mulheres na ciência: o interesse das estudantes brasileiras pela carreira científica. Educación Química, 25(4), 407-417. Retrieved from https://bit.ly/2BRzenE

De Luca, M. M. M., Cardoso, V. I. da C., Vasconcelos, A. C. de, \& Pontes, A. B. (2014). Análise da produção científica referente à temática de sustentabilidade em pesquisas da Administração. Administração: Ensino e Pesquisa, 15(3), 469-500. Retrieved from https://bit.ly/2BPWxyh

De Luca, M. M. M., Gomes, C. A. S., Corrêa, D. M. M. C., \& Domingos, S. R. M. (2011). Participação 
feminina na produção científica em contabilidade publicada nos anais dos eventos Enanpad, Congresso USP de Controladoria e Contabilidade e congresso Anpcont. Revista de Contabilidade e Organizações, 5(11), 45-164. Retrieved from https://bit.ly/2E0MFDh

Gil, A. C. (2014). Métodos e técnicas de pesquisa social (6. ed.). São Paulo: Atlas.

Greenbaum, H. K., Goodsir, H. L., Smith, M. C., \& Robinson, D. H. (2018). Female participation as top-producing authors, editors, and editorial board members in educational psychology journals from 2009 to 2016. Educational Psychology Review, 30(4), 1283-1289. Retrieved from https://link.springer.com/article/10.1007/s10648-018-9452-8

Guedes, M. de C., Azevedo, N., \& Ferreira, L. O. (2015). A produtividade científica tem sexo? Um estudo sobre bolsistas de produtividade do CNPq. Cadernos Pagu, 45(1), 367-399. Retrieved from https://goo.gl/YKpmW3

Guimarães, C. R. F. F., \& Silva, J. R. (2015). Diferenças de salários, por género, no setor de turismo do Brasil. Revista Turismo e Desenvolvimento, s.v.(23), 143-154. Retrieved from https://bit.ly/2E6faQ7

Henrique, M. R., Henrique, M. R., Soares, W. A., \& Silva, S. R. da. (2018). Determinantes da estrutura de capital de empresas brasileiras: uma análise empírica das teorias de Pecking Order e TradeOff no período de 2005 e 2014. Revista Ibero-Americana de Estratégia, 17(1), 130-144. Retrieved from https://bit.ly/2E08yCB

Hirata, H. (2018). Gênero, patriarcado, trabalho e classe. TrabalhoNecessário, 16(29), 14-28. Retrieved from https://bit.ly/2rjxYUg

Joly, M. C. R. A., Bustamante, M. I., \& Oliveira, S. M. da S. S. (2015). Análise da produção científica em artigos sobre estudos transculturais na avaliação psicológica em bases online. Acta Colombiana de Psicología, 18(1), 173-183. Retrieved from https://bit.ly/2QyGFYV

Leite, J. Y. P., Oliveira, A. S., \& Frutuoso, N. V. L. (2018). Genre analysis in the scientific participation in mineral technology. HOLOS, 4(34), 253-260. Retrieved from https://bit.ly/2EOMxDN

Leta, J. (2003). As mulheres na ciência brasileira: crescimento, contrastes e um perfil de sucesso. Estudos Avançados, 17(49), 271-284. Retrieved from http://www.scielo.br/pdf/ea/v17n49/18408.pdf

Lima, M. V. A. de, Lima, C. R. M. de, Lima, M. A. de, \& Pereira, M. F. (2012). Apoio multicritério na gestão da estrutura de capital de pequenas e médias empresas. Revista Gestão \& Tecnologia, 12(3), 146-173. Retrieved from https://bit.ly/2wlm6kf

Lino, T. R., \& Mayorga, C. (2016). As mulheres como sujeitos da ciência: uma análise da participação das mulheres na ciência moderna. Saúde \& Transformação Social, 7(3), 96-107. Retrieved from https://goo.gl/jwy8Uu

Macaluso, B., Larivière, V., Sugimoto, T., \& Sugimoto, C. R. (2016). Is science built on the shoulders of women? A study of gender differences in contributorship. Academic Medicine, 91(8), 1136- 
1142.

Retrieved

from

https://www.ingentaconnect.com/content/wk/acm/2016/00000091/00000008/art00027

Machado, M. C. F., Souza, M. A. de, \& Mello-Carpes, P. B. (2018). Mulheres na ciência: divulgando possibilidades de carreira científica com escolares. Revista Ciência Em Extensão, 14(1), 43-53. Retrieved from https://bit.ly/2QdETOb

Mantezelli, B. R., Nobre, F. C., Nobre, L. H. N., Sousa, A. J. de, \& Calil, J. F. (2017). O nível de endividamento e os determinantes da estrutura de capital das empresas listadas no novo mercado da BM\&amp; FBovespa. Revista Eletrônica de Administração, 16(1), 43-64. Retrieved from https://bit.ly/2FXSIAp

Mello, C. M. de, Crubellate, J. M., \& Rossoni, L. (2009). Rede de coautorias entre docentes de programas brasileiros de pós-graduação (stricto sensu) em administração: aspectos estruturais e dinâmica de relacionamento. Revista de Administração Mackenzie, 10(5), 130-155. Retrieved from https://bit.ly/2Uk9PtU

Modigliani, F., \& Miller, M. H. (1958). The cost of capital, corporation finance and theory of investment. The American Economic Review, 48(3), 261-297. Retrieved from https://bit.ly/2FHQGPy

Modigliani, F., \& Miller, M. H. (1963). Corporate income taxes and the cost of capital: a correction. The American Economic Review, 53(3), 433-443. Retrieved from https://bit.ly/2Fibcpt

Morais, C. R. F. de, Cabral, A. C. de A., Pessoa, M. N. M., Oliveira, L. V. C., Santos, S. maria dos, \& Silva, C. R. M. da. (2018). A participação feminina na produção científica das áreas de Administração e Ciências Contábeis. Revista de Contabilidade Da UFBA, 12(2), 61-97. Retrieved from https://bit.ly/2AOtE3L

Myers, S. C. (1984). The capital structure puzzle. The Journal of Finance, 39(3), 575-592. Retrieved from https://bit.ly/2OFyzJj

Nakamura, E. A. M. V., Jones, G. D. C., \& Nakamura, W. T. (2017). Panorama da produção científica brasileira sobre estrutura de capital e as principais teorias abordadas: um estudo bibliométrico. Revista de Administração de Roraima, 7(2), 310-330. Retrieved from https://revista.ufrr.br/adminrr/article/view/4383/pdf

Olinto, G. (2011). A inclusão das mulheres nas carreiras de ciência e tecnologia no Brasil. Inclusão Social, 5(1), 68-77. Retrieved from https://bit.ly/2QyPLoN

Oliveira, E. C. de, Pereira, R. da S., \& Gaspar, M. A. (2014). Análise da produção científica nacional sobre gestão ambiental no setor sucroenergético brasileiro. Revista Gestão e Sustentabilidade Ambiental, 3(1), 39-63. Retrieved from https://bit.ly/2AQmP1r

Padilha, D. F., \& Silva, T. P. da. (2016). Relação entre o market timing e a estrutura de capital de empresas de alta tecnologia: um estudo usando a teoria dos jogos. ConTexto, 16(33), 41-57. Retrieved from https://bit.ly/2BQA44g 
Pritchard, A. (1969). Statistical bibliography or bibliometrics? Journal of Documentation, 25(4), 348349. Retrieved from https://bit.ly/2E1INSI

Prodanov, C. C., \& Freitas, E. C. De. (2013). Metodologia do trabalho científico: métodos e técnicas da pesquisa e do trabalho acadêmico. Novo Hamburgo: Feevale (2. ed.). Novo Hamburgo: Feevale. https://doi.org/10.1017/CBO9781107415324.004

Quevedo-Silva, F., Santos, E. B. A., Brandão, M. M., \& Vils, L. (2016). Estudo bibliométrico: orientações sobre sua aplicação. Revista Brasileira de Marketing, 15(2), 246-262. Retrieved from https://bit.ly/2EbGBrz

Ramos, R. C., \& Tedeschi, S. P. (2015). A participação das mulheres na produção científica da UNESP, campus de Rio Claro. Caderno Espaço Feminino, 28(1), 140-152. Retrieved from https://bit.ly/2QBQhIR

Resende, M. C. R., Ramos, M. A., Melo, A. A. de O., Tomaz, C. M., Pacheco, M. H. S., \& Silva, W. A. C. (2012). Participação feminina na produção científica em finanças nos ENANPAD's de 2000 a 2010. Revista Ciências Sociais Em Perspectiva, 11(20), 1-22. Retrieved from https://goo.gl/GC9Y7N

Ribeiro, H. C. M., \& Costa, B. K. (2013). Brazilian Administration Review: uma análise do perfil da produção acadêmica científica no período de 2004 a 2012 sob a ótica da rede social e da bibliometria. Revista de Ciências Da Administração, 15(37), 65-81. Retrieved from https://periodicos.ufsc.br/index.php/adm/article/view/2175-8077.2013v15n37p65/26103

Rosa, M. A. G., \& Quirino, R. G. (2016). Relações de gênero na Ciência e Tecnologia (C\&T): estudo de caso de um Centro Federal de Educação Tecnológica. Revista Diversidade e Educação, 4(8), 4255. Retrieved from https://bit.ly/2AVA2tb

Sánchez-Perdomo, R., Rosario-Sierra, M., Herrera-Vallejera, D., Rodríguez-Sánchez, Y., \& CarrilloCalvet, H. (2017). Revisión bibliométrica de las Ciencias de la Información en América Latina y el Caribe. Investigación Bibliotecológica: Archivonomía, Bibliotecología e Información, Especia/(1), 79-100. Retrieved from https://bit.ly/2IPsCgK

Santos, C. M. M., Carvalho Neto, A., Caeiro, M., Versiani, F., \& Martins, M. G. (2016). As mulheres estão quebrando as três paredes de vidro? Um estudo com empreendedoras mineiras. Economia e Gestão, 16(45), 126-149. Retrieved from https://bit.ly/2Sw9faK

Schiebinger, L. (2001). O feminismo mudou a ciência? (1st ed.). Bauru: EDUSC.

Schroeder, R. G., Clark, M. W., \& Cathey, J. M. (2005). Financial accounting theory and analysis (8th ed.). Danvers: John Wiley \& Sons.

Serrano, S. C. (2018). Producción científica internacional sobre gestión de proyectos en el área de Información y Documentación: 1996-2015. Investigación Bibliotecológica: Archivonomía, Bibliotecología e Información, 32(75), 125-144. Retrieved from https://bit.ly/2NjWApP

Shyam-Sunder, L., \& Myers, S. C. (1999). Testing static tradeoff against pecking order models of 
capital structure. Journal of Financial Economics, 51(1), 219-244. Retrieved from https://goo.gl/9fEVpE

Soares, T. A. (2001). Mulheres na ciência e tecnologia: ascensão limitada. Química Nova, 24(2), 281285. Retrieved from https://bit.ly/2Qdqp07

Souza, R. M. F. de, Baia, M. W. M., Costa, I. C. M., Machado, R. S., Mendes, A. L. B., \& Souto, M. V. (2017). Análise bibliométrica dos artigos científicos em finanças publicados na Revista de Administração de Empresas (RAE) da FGV/SP, no período de 2006 a 2016. Administração: Ensino e Pesquisa, 18(3), 489-517. Retrieved from https://bit.ly/2zJwlnm

Souza, J. G. S., Popoff, D. A. V., Torres, S. de A. S., Mourão, F. R., Martelli Junior, H., Moreira, A. N., \& Martins, A. M. E. de B. L. (2014). Perfil e produção científica dos pesquisadores brasileiros do CNPq em Periodontia. PerioNews, 8(2), 172-178. Retrieved from https://bit.ly/2BR8zao

Souza, K. R., \& Kerbauy, M. T. M. (2017). Abordagem quanti-qualitativa: superação da dicotomia quantitativa-qualitativa na pesquisa em educação. Educação e Filosofia, 31(61), 21-44. Retrieved from https://bit.ly/2LOE5Z3

Tsuji, C. (2011). A survey of the trade-off theory of corporate financing. Business and Management Review, 1(6), 102-107. Retrieved from https://goo.gl/UjHznv

Vanti, N. A. P. (2002). Da bibliometria à webometria: uma exploração conceitual dos mecanismos utilizados para medir o registro da informação e a difusão do conhecimento. Ciência Da Informação, 31(2), 369-379. Retrieved from http://www.scielo.br/pdf/ci/v31n2/12918.pdf

Velho, L., \& León, E. (1988). A construção social da produção científica por mulheres. Cadernos Pagu, 10(1), 309-344. Retrieved from https://bit.ly/2vrAXN5 